\title{
Profil Indeks Pengembangan Ikatan-Silang Gelatin-Kitosan
}

\author{
Swelling Index Profile of Cross-link Gelatin-Chitosan
}

\author{
Nursalam Hamzah ${ }^{1}$, Muhammad Fadhlurrahman ${ }^{2}$, Surya Ningsi ${ }^{1}$, Haeria ${ }^{1}$ \\ ${ }^{1}$ Jurusan Farmasi Fakultas Kedokteran dan Ilmu Kesehatan Universitas Islam Negeri Alauddin Makassar, Jl. H. \\ M. Yasin Limpo No. 36, Kecamatan Sombaopu, Kabupaten Gowa, Sulawesi Selatan \\ ${ }^{2}$ Mahasiswa Prodi Farmasi Fakultas Kedokteran dan Ilmu Kesehatan Universitas Islam Negeri Alauddin \\ Makassar, Jl. H. M. Yasin Limpo No. 36, Kecamatan Sombaopu, Kabupaten Gowa, Sulawesi Selatan
}

Kontak*: nursalamhamzah@uin-alauddin.ac.id

\begin{abstract}
ABSTRAK
Gelatin ikan menjadi sumber alternatif gelatin halal, tetapi memiliki sifat mekanik dan kekuatan gel yang rendah. Ikat silang telah banyak digunakan pada modifikasi material, termasuk untuk membentuk kompleks gelatinkitosan. Ikat silang dapat meningkatkan kemampuan sifat mekanik dan kekuatan gel. Fokus penelitian ini adalah mengamati karakteristik indeks pengembangan kompleks gelatin-kitosan yang diikat silang menggunakan glutaraldehid dan sukrosa teroksidasi dengan variasi konsentrasi. Penelitian dimulai dengan ekstraksi gelatin dari sisik ikan Bandeng menggunakan metode basa-asam. Gelatin sisik ikan Bandeng dan gelatin komersil kemudian digunakan sebagai sampel. Larutan gelatin, kitosan dan pengikat silang dicampurkan dan diinkubasi pada suhu $40^{\circ} \mathrm{C}$ selama selama $24 \mathrm{jam}$. Campuran kemudian dikeringkan pemanasan suhu $70^{\circ} \mathrm{C}$ sampai sampel kering. Sampel kemudian diuji indeks pengembangan dengan direndam dalam air selama 12 jam, volume pengembangan diamati tiap jam. Hasil yang diperoleh menunjukkan bahwa kompleks gelatin-kitosan dapat diikat metode ikat silang dengan glutaraldehid dan sukrosa teroksidasi yang ditunjukkan dengan perubahan nilai indeks pengembangan. Sukrosa teroksidasi dengan perbandingan sukrosa dan natrium periodat 1:3 menunjukkan nilai indeks pengembangan paling baik.
\end{abstract}

Kata Kunci: Indeks Pengembangan, Gelatin, Kitosan, Ikat Silang, Komposit

\begin{abstract}
Fish gelatin is an alternative for halal gelatin, but has low mechanical properties and gel strength. Crosslinking has been widely used in material modification, including for forming gelatin-chitosan complexes. Cross-linking can improve the mechanical and gel strength properties. The focus of this study is to observe the characteristics of swelling index of a crosslinked gelatin-chitosan complex using glutaraldehyde and oxidized sucrose with varying concentrations. The study began with extraction of gelatin from milkfish scales using an acidbase method. Milkfish gelatin and commercial gelatin are then used as samples. Gelatin, chitosan and crosslinker solutions were mixed and incubated at $40^{\circ} \mathrm{C}$ for 24 hours. Then the mixture is dried at temperature $70^{\circ} \mathrm{C}$ until the sample is dry. The sample then tested for swelling index by immersing it in water for 12 hours, the swelling volume is observed every hour. The results showed that the gelatin-chitosan complex can be cross-linked with glutaraldehyde and oxidized sucrose, indicated by decrease of swelling index. Oxidized sucrose with sucrose and sodium periodate ratio 1: 3 showed the favorable swelling index value.
\end{abstract}

Keywords: Swelling Index, Gelatin, Chitosan, Crosslinking, Composite

\section{PENDAHULUAN}

Sumber utama pembuatan gelatin adalah berasal dari babi, kulit dan tulang sapi, serta alternatif baru seperti ikan. Gelatin ikan menjadi sumber alternatif dalam beberapa tahun terakhir mengingat penyakit sapi gila, dan larangan penggunaan kulit dan tulang babi karena alasan agama (Hosseini, Rezaei, Zandi, \& Ghavi, 2013). Gelatin yang berasal dari sisik ikan merupakan salah satu bahan 
alternatif potensial pengganti gelatin tulang babi dan tulang sapi yang pada umumnya dipakai di industri. Sisik ikan merupakan salah satu bagian terbesar produk yang belum dimanfaatkan secara maksimal sebagai hasil samping usaha industri perikanan laut yang menyebabkan limbah dan polusi pada lingkungan (Erizal, Perkasa, Abbas, \& S., 2013). Gelatin dapat diperoleh dengan cara sederhana dari limbah ikan (Tylingo, Gorczyca, Mania, Szweda, \& Milewski, 2016).

Ikan bandeng merupakan salah satu ikan dengan produksi yang besar khususnya di provinsi Sulawesi Selatan pada tahun 2015 (Direktorat Produksi dan Usaha Budidaya, 2016). Produksi ikan bandeng pastinya menyisakan limbah, salah satunya ialah sisik ikan itu sendiri. Padahal, sisik ikan, termasuk Bandeng, pada dasarnya mengandung kolagen/gelatin yang bernilai ekonomis (Erizal, Perkasa, Abbas, \& S., 2013). Saat ini, ketertarikan terhadap gelatin ikan masih kecil dikarenakan stabilitasnya yang rendah dibandingkan gelatin yang diperoleh dari hewan darat (Tylingo, Gorczyca, Mania, Szweda, \& Milewski, 2016).

Gelatin digunakan secara luas dalam bidang medis seperti plester penyembuhan luka, kulit artifisial, bahan rekayasa jaringan dan bahan baku cangkang kapsul (Dragusin, et al., 2012; Huang, et al., 2013). Tetapi, gelatin memiliki sifat mekanik yang lemah, kelarutan tinggi dalam media air dan tidak ada aktivitas antimikroba untuk mencegah infeksi luka, sehingga membatasi aplikasinya dalam bidang biomedis (Stancu, et al., 2013; Koser, Chinn, \& Saunders, 1938). Kekurangan tersebut dapat diatasi dengan kombinasi dengan kitosan, suatu polisakarida yang diperoleh dari deasetilasi kitin. Kitosan memiliki keuntungan khusus seperti kemampuan pembentukan film, biokompatibilitas dan biodegradabilitas yang baik (Li, Ma, D., \& Zhu, 2012; Jayasuriya \& Kibbe, 2010). Selain itu, kitosan juga memiliki aktivitas antibakteri (Wang, Hong, Chen, Lian, \& Xiong, 2012; Wu, Ji, Chang, Yang, \& Lee, 2012).

Kombinasi protein-polisakarida menunjukkan aplikasi yang menjanjikan di bidang biomedis karena biokompatibilitasnya, kemampuan terurai secara hayati dan tidak beracun (Jătariu (Cadinoiu), Popa, Curteanu, \& Peptu, 2011). Ketika dicampur bersama, gelatin dan kitosan dapat saling melengkapi dan meningkatkan sifat-sifat seperti sifat mekanik dan bioaktivitas antibakteri. Namun, campuran fisik sederhana memiliki stabilitas dan kekuatan mekanik yang rendah, tetapi sifat ini cukup yang penting untuk banyak aplikasi. Oleh karena itu, metode seperti ikatan silang kovalen antara molekul polimer diperlukan untuk menambah stabilitas dan kekuatan mekanik (Jătariu (Cadinoiu), et al., 2013; Mishra, et al., 2011).

Kombinasi interaksi elektrostatik dan ikatan silang kovalen membentuk kompleks gelatin-kitosan dengan karakteristik mekanik yang kuat. Karakter kationik kitosan dalam 
kondisi asam memberikan peluang untuk terbentuknya interaksi elektrostatik dengan senyawa bermuatan negatif lainnya. Karena karakteristik ini, kitosan banyak digunakan untuk produksi film yang aman dimakan serta bahan polimer bio-kompatibel (Aider, 2010; Rivero, García, \& Pinnoti, 2010).

Gelatin merupakan bahan yang diperoleh dari kolagen dengan hidrolisis yang ada di tulang dan kulit. Bahan ini dikenal karena kemampuan pembentukan filmnya yang sangat baik, karena sifat penghalang yang baik untuk oksigen dan cahaya, yang diaplikasikan pada cangkang kapsul keras (Hoque, Benjakul, \& Prodpran, 2011). Kitosan dan gelatin telah terbukti kompatibel karena pembentukan ikatan elektrostatik dan hidrogen ketika kitosan bermuatan positif dan gelatin bermuatan negatif pada kondisi $\mathrm{pH}$ yang sesuai. Untuk meningkatkan penghalang air dan sifat mekanik kompleks proteinpolisakarida, zat-zat pengikat silang kimia dapat ditambahkan (Farris, Song, \& Huang, 2010). Aldehid adalah salah satu golongan senyawa yang dapat mengikat silang gelatin dan polisakarida (Huang, et al., 2019). Pengikat-pengikat silang golongan aldehid yang umum digunakan termasuk glutaraldehid dan sukrosa teroksidasi (Bigi, Cojazzi, Panzavolta, Rubini, \& Roveri, 2001; El-Feky, Zayed, Elshaier, \& Alsharif, 2018). Sukrosa teroksidasi digunakan sebagai bahan pengikat silang karena selain hemat biaya, juga memiliki toksisitas yang rendah dan glutaraldehid karena mudah tersedia, murah dan efektif dalam ikatan silang (Bigi, Cojazzi, Panzavolta, Rubini, \& Roveri, 2001). Glutaraldehid dan sukrosa teroksidasi dapat membentuk ikatan silang dengan gugus asam amino rantai polipeptida, meningkatkan interaksi antar molekul protein gelatin (Bigi, Bracci, Cojazzi, Panzavolta, \& Roveri, 1998).

Salah satu karakter penting untuk menilai kualitas kompleks gelatin-kitosan adalah indeks pengembangan. Penelitian ini bermaksud memperbaiki sifat gelatin ikan sehingga memiliki kualitas lebih baik. Tujuan dari penelitian ini adalah untuk menganalisis efek sinergis dari penggabungan gelatin dengan kitosan dengan penambahan pengikat silang glutaraldehid dan sukrosa teroksidasi pada sifat indeks pengembangan. Pencampuran gelatin dengan kitosan menjadi cara yang menjanjikan untuk memperoleh biopolimer dengan sifat baru (Qiao, Ma, Zhang, \& Yao, 2017; Wang, et al., 2015; Benbettaïeb, Karbowiak, Brachais, \& Debeaufort, 2015).

\section{METODE PENELITIAN}

\section{Ekstraksi Gelatin dari Sisik Ikan Bandeng}

Sampel gelatin yang digunakan dalam pembuatan kompleks gelatin kitosan adalah gelatin sisik ikan Bandeng. Proses ekstraksi gelatin melalui lima tahapan yaitu sortasi, pra-ekstraksi basa, pra-ekstraksi asam, ekstraksi dengan air, dan pengeringan. Sortasi dimaksudkan untuk membersihkan bagian kulit dan lemak, kemudian sampel dikeringkan. Sampel kering sebanyak 100 g 
direndam larutan $\mathrm{NaOH} 1 \mathrm{~N}$ sebanyak $700 \mathrm{ml}$ selama 60 menit. Setelah perendaman basa, sampel dicuci dengan dengan air suling 700 ml sebanyak 3 kali, disaring. Kemudian ampas sampel direndam larutan $\mathrm{HCl} 1 \mathrm{~N}$ sebanyak $700 \mathrm{ml}$. Setelah perendaman asam, sampel dicuci dan disaring sebagaimana pencucian pada pra-ekstraksi basa. Kemudian ampas direndam dengan air suling sebanyak $700 \mathrm{ml}$ pada suhu $90^{\circ} \mathrm{C}$ selama 8 jam. Sampel kemudian saring. Filtrat dikeringkan dalam oven pada suhu $80^{\circ} \mathrm{C}$, kira-kira selama 2 hari (Hamzah, Nurmi, Mukhriani, \& Ismail, 2019).

\section{Modifikasi Gelatin-Kitosan Ikatan Silang}

Pembuatan larutan gelatin 5\% dan kitosan $1 \%$

Sampel gelatin yang digunakan adalah gelatin sisik ikan Bandeng dan Gelatin Komersil. Larutan gelatin dibuat dengan cara melarutkan 5 g gelatin dalam $95 \mathrm{ml}$ air suling pada suhu $60^{\circ} \mathrm{C}$ dengan pengadukan kemudian didinginkan pada suhu kamar. Larutan kitosan dibuat dengan melarutkan $1 \mathrm{~g}$ kitosan dalam $95 \mathrm{ml}$ asam asetat $1 \%$ dan dibiarkan selama semalam. Volume akhir larutan gelatin atau kitosan dicukupkan hingga $100 \mathrm{ml}$ dalam labu ukur dengan pelarut yang sesuai.

\section{Pembuatan larutan sukrosa teroksidasi}

Larutan sukrosa teroksidasi dibuat dengan cara sukrosa dan natrium periodat dengan rasio mol 1:2 (SBC 1 dan SKC 1); 1:3 (SBC 2 dan SKC 2) dan 1:4 (SBC 3 dan SKC 3), dilarutkan dalam air suling sebanyak $25 \mathrm{ml}$ dalam Erlenmeyer (lihat tabel 1). Selanjutnya erlenmeyer dibungkus dengan aluminium foil dan didiamkan pada suhu kamar selama 6 jam. Kemudian barium klorida $\left(\mathrm{BaCl}_{2} .2 \mathrm{H}_{2} \mathrm{O}\right)$ sebanyak $120 \mathrm{mg}$ ditambahkan dalam larutan pada suhu kamar selama 2 jam. Endapan disaring dan filtrat dipisahkan (El-Feky, Zayed, Elshaier, \& Alsharif, 2018).

\section{Pembuatan Ikatan silang}

Larutan gelatin $50 \mathrm{ml}$ dimasukkan ke dalam erlenmeyer kemudian ditambahkan dengan larutan kitosan $50 \mathrm{ml}$ lalu diaduk. Larutan sukrosa teroksidasi atau glutaraldehid (lihat tabel 1) ditambahkan ke dalam erlenmeyer dan diaduk. Kemudian campuran diinkubasi dalam inkubator pada suhu $40^{\circ} \mathrm{C}$ selama 24 jam lalu dikeringkan dalam oven pada suhu $70^{\circ} \mathrm{C}$. Kompleks gelatin-kitosan selanjutnya dihaluskan (Patel, Srivastava, Singh, \& Singh, 2018; El-Feky, Zayed, Elshaier, \& Alsharif, 2018). Sebagai kontrol, dibuat blangko campuran fisik tanpa bahan pengikat silang, kelompok BC dan KC (Qiao, Ma, Zhang, \& Yao, 2017).

\section{Pengamatan organoleptik}

Identifikasi secara organoleptik dilakukan dengan cara diamati bentuk, warna dan bau dari gelatin sampel yang telah kering.

\section{Pengujian Indeks Pengembangan}

Sampel sebanyak 2 g dimasukkan ke dalam gelas ukur, dimampatkan dan dicatat volume sebagai volume awal (V0). Selanjutnya ditambahkan air suling sebanyak 
Tabel 1. Kelompok percobaan

\begin{tabular}{|c|c|c|c|c|c|c|c|}
\hline \multirow[t]{3}{*}{ Kode } & \multicolumn{7}{|c|}{ Komposisi Bahan } \\
\hline & \multirow{2}{*}{$\begin{array}{c}\text { Glutaraldehid } \\
25 \% \\
\mathrm{ml}\end{array}$} & \multicolumn{3}{|c|}{ Sukrosa teroksidasi } & \multirow{2}{*}{$\begin{array}{l}\text { Gelatin } \\
\text { Ikan 5\% } \\
\text { ml }\end{array}$} & \multirow{2}{*}{$\begin{array}{l}\text { Gelatin } \\
\text { Komersil } \\
5 \% \\
\mathrm{ml}\end{array}$} & \multirow{2}{*}{$\begin{array}{c}\text { Kitosan } \\
1 \% \\
\mathrm{ml}\end{array}$} \\
\hline & & $\begin{array}{c}\text { Sukrosa } \\
\mathrm{g}\end{array}$ & $\begin{array}{c}\text { Natrium } \\
\text { periodat } \\
\mathrm{g}\end{array}$ & $\begin{array}{c}\text { Air } \\
\text { suling } \\
\text { ml }\end{array}$ & & & \\
\hline GBC 1 & 0,15 & - & - & - & 50 & - & 50 \\
\hline GBC 2 & 0,3 & - & - & - & 50 & - & 50 \\
\hline GBC 3 & 0,6 & - & - & - & 50 & - & 50 \\
\hline GKC 1 & 0,15 & - & - & - & - & 50 & 50 \\
\hline GKC 2 & 0,3 & - & - & - & - & 50 & 50 \\
\hline GKC 3 & 0,6 & - & - & - & - & 50 & 50 \\
\hline SBC 1 & - & 0,25 & 0,31 & ad 25 & 50 & - & 50 \\
\hline SBC 2 & - & 0,25 & 0,46 & ad 25 & 50 & - & 50 \\
\hline SBC 3 & - & 0,25 & 0,62 & ad 25 & 50 & - & 50 \\
\hline SKC 1 & - & 0,25 & 0,31 & ad 25 & - & 50 & 50 \\
\hline SKC 2 & - & 0,25 & 0,46 & ad 25 & - & 50 & 50 \\
\hline SKC 3 & - & 0,25 & 0,62 & ad 25 & - & 50 & 50 \\
\hline $\mathrm{BC}$ & - & - & - & - & 50 & - & 50 \\
\hline $\mathrm{KC}$ & - & - & - & - & - & 50 & 50 \\
\hline
\end{tabular}

50 ml kemudian sampel dibiarkan mengembang selama 12 jam. Volume pengembangan $(\mathrm{V})$ diamati tiap jam. Indeks pengembangan (IP) dihitung dengan rumus (Hamzah, Nurmi, Mukhriani, \& Ismail, 2019):

$$
I P=\frac{V-V 0}{V 0} X 100 \%
$$

Selain itu juga diujikan juga bahan penyusunnya masing-masing yaitu kontrol Gelatin Bandeng, Komersil dan Kitosan, serta Gelatin Standar Sapi (Gelatin from bovine skin gel strength $225 \mathrm{~g}$ Bloom).

\section{PEMBAHASAN}

Gelatin ikan bandeng yang digunakan diperoleh dari ekstraksi gelatin sisik ikan bandeng (Chanos chanos) dengan metode basa dan asam. Pra-ekstraksi dengan basa dan asam bertujuan untuk melarutkan kontaminan lemak, protein atau bahan lain yang larut dalam basa dan asam serta memecah ikatan kovalen dari kolagen sehingga sisik melunak. Gelatin sendiri sukar larut dalam basa dan asam. Basa dan asam dengan konsentrasi tinggi membantu melunakkan sampel sehingga mempermudah dalam ekstraksi dalam air. Penggunaan air berguna melarutkan gelatin, dengan penambahan pemanasan untuk meningkatkan penetrasi dan kelarutan gelatin dalam air. Pemanasan pada suhu $90^{\circ} \mathrm{C}$ membantu memecah rantai heliks pada kolagen menjadi rantai gelatin. Gelatin merupakan turunan dari kolagen. Pemanasan yang terlalu lama akan memecah gelatin menjadi sangat kecil, tetapi terlalu cepat menurunkan jumlah rendemen, sehingga durasi dan suhu pemanasan perlu dikontrol (Schrieber \& Gareis, 2007).

Kompleks gelatin-kitosan dibentuk dengan metode ikat silang menggunakan 
Tabel 2. Profil organoleptik kompleks gelatin-kitosan

\begin{tabular}{cccc}
\hline \multirow{2}{*}{ Kelompok } & \multicolumn{3}{c}{ Identifikasi } \\
\cline { 2 - 4 } & Bentuk & Warna & Bentuk \\
\hline GBC 1 & Kepingan & Coklat Kehitaman & Khas \\
GBC 2 & Kepingan & Coklat & Khas \\
GBC 3 & Kepingan & Coklat & Khas \\
GKC 1 & Kepingan & Coklat Kehitaman & Khas \\
GKC 2 & Kepingan & Coklat & Khas \\
GKC 3 & Kepingan & Coklat & Khas \\
SBC 1 & Kepingan & Coklat Pucat & Khas \\
SBC 2 & Kepingan & Coklat Pucat & Khas \\
SBC 3 & Kepingan & Coklat & Khas \\
SKC 1 & Kepingan & Coklat Pucat & Khas \\
SKC 2 & Kepingan & Coklat Pucat & Khas \\
SKC 3 & Kepingan & Coklat & Khas \\
BC & Kepingan & Kuning pucat & Tidak berbau \\
KC & Kepingan & Kuning pucat & Tidak berbau \\
Gelatin Bandeng & Kepingan & Kuning pucat & Tidak berbau \\
Gelatin Komersil & Serbuk kasar & Kuning pucat & Tidak berbau \\
Gelatin Sapi & Serbuk halus & Kuning pucat & Tidak berbau \\
Kitosan & Serbuk kasar ringan & Kuning pucat & Tidak berbau \\
\hline
\end{tabular}

glutaraldehid dan sukrosa teroksidasi. Glutaraldehid memiliki dua gugus karbonil sedangkan sukrosa teroksidasi yang dihasilkan dari oksidasi menggunakan natrium periodat menghasilkan senyawa dengan dua karbonil atau empat karbonil. Jika hanya salah satu dari unit gula yang teroksidasi, maka membentuk dua gugus karbonil, sedangkan jika dua unit gula maka membentuk empat gugus karbonil (Jalaja \& James, 2015). Setiap gugus karbonil dapat bereaksi dengan gugus amin pada lisin dalam gelatin atau glukosamin (monomer kitosan) membentuk gugus imin $(-\mathrm{C}=\mathrm{N}-)$ dengan mekanisme reaksi Schiff base. Gugus karbonil $(\mathrm{C}=\mathrm{O})$ juga bereaksi dengan gugus hidroksil pada glukosamin membentuk struktur $\mathrm{C}-\mathrm{O}-$ $\mathrm{C}-\mathrm{O}-\mathrm{C}$ dengan mekanisme asetalisasi. Kompleks ikatan silang dapat terjadi antara gelatin-kitosan, kitosan-kitosan dan gelatin- gelatin (Qian, Zhang, Chen, Ke, \& Mo, 2011). Gelatin dan kitosan jika tidak diikat silang juga akan saling berinteraksi melalui ikatan hidrogen dan elektrostatik walaupun interaksinya lemah. Dalam suasana asam, interaksi elektrostatik dapat terbentuk melalui interaksi antara gugus amin yang meng-ion $\left(\mathrm{NH}_{3}{ }^{+}\right)$bermuatan positif dengan ion karboksilat $\left(\mathrm{COO}^{-}\right)$yang bermuatan . Selain itu, ikatan hidrogen juga dapat terbentuk antar gugus polar dalam kitosan seperti amin $\left(\mathrm{NH}_{2}\right)$ dan hidroksil $(\mathrm{OH})$ dengan karboksilat $(\mathrm{COOH})$, amin atau hidroksil pada gelatin. Ikatan tersebut dapat pula dimediasi oleh air, gelatin mengandung air sekitar 10\% (Qiao, Ma, Zhang, \& Yao, 2017; Staroszczyk, Sztuka, Wolska, Wojtasz-Pająk, \& Kołodziejska, 2014; Qian, Zhang, Chen, Ke, \& Mo, 2011). Besarnya ikatan kovalen, hidrogen atau elektrostatik ini berpengaruh 
Tabel 3. Indeks pengembangan kompleks gelatin-kitosan (IP)

\begin{tabular}{|c|c|c|c|c|c|c|c|c|c|c|c|c|c|c|}
\hline \multirow{2}{*}{$\begin{array}{l}\text { Kelom- } \\
\text { pok }\end{array}$} & \multicolumn{13}{|c|}{ Volume Pengembangan pada jam ke- $(\mathrm{ml})$} & \multirow{2}{*}{$\operatorname{IP}(\%)$} \\
\hline & 0 & 1 & 2 & 3 & 4 & 5 & 6 & 7 & 8 & 9 & 10 & 11 & 12 & \\
\hline GBC 1 & 3,0 & 9,0 & 10,5 & 10,5 & 10,5 & 11,0 & 11,0 & 11,0 & 11,5 & 11,5 & 11,5 & 11,5 & 11,5 & 283,3 \\
\hline GBC 2 & 4,0 & 13,0 & 14,0 & 14,0 & 14,0 & 14,0 & 14,0 & 14,0 & 14,0 & 14,0 & 14,0 & 14,0 & 14,0 & 250 \\
\hline GBC 3 & 4,0 & 13,0 & 14,5 & 14,5 & 14,5 & 14,5 & 14,5 & 14,5 & 14,5 & 14,5 & 14,5 & 14,5 & 14,5 & 262,5 \\
\hline GKC 1 & 3,5 & 10,0 & 11,5 & 11,5 & 12,0 & 12,0 & 12,0 & 12,0 & 12,0 & 12,0 & 12,0 & 12,0 & 12,0 & 242,9 \\
\hline GKC 2 & 4,5 & 13,0 & 15,5 & 15,5 & 15,5 & 15,5 & 15,5 & 15,5 & 15,5 & 15,5 & 15,5 & 15,5 & 15 , & 244,4 \\
\hline GKC 3 & 5,0 & 16,0 & 18,0 & 18,0 & 18,0 & 18,0 & 18,0 & 18,0 & 18,0 & 18,0 & 18,0 & 18,0 & 18,0 & 0 \\
\hline SBC 1 & 4,0 & 8,0 & 10,0 & 10,0 & 10,0 & 10,0 & 10,0 & 10,0 & 10,0 & 10,5 & 10,5 & 10,5 & 10,5 & 162,5 \\
\hline SBC 2 & 6,0 & 9,0 & 10,0 & 10,0 & 10,5 & 10,5 & 10,5 & 10,5 & 10,5 & 10,5 & 10,5 & 10,5 & 10 & 75 \\
\hline SBC 3 & 5,0 & 9,0 & 11,0 & 11,0 & 11,5 & 11,5 & 11,5 & 11,5 & 11,5 & 11,5 & 11,5 & 11,5 & 11 , & 130 \\
\hline SKC 1 & 4,0 & 8,0 & 10,0 & 10,0 & 10,0 & 10,0 & 10,0 & 10,0 & 10,0 & 10,0 & 10,0 & 10,0 & 10,0 & 150 \\
\hline SKC 2 & 4,5 & 9,0 & 9,5 & 9,5 & 9,5 & 9,5 & 9,5 & 9,5 & 9,5 & 9,5 & 9,5 & 9,5 & 9,5 & 111,1 \\
\hline SKC 3 & 4,0 & 10,0 & 10,5 & 10,5 & 10,5 & 10,5 & 10,5 & 10,5 & 11,0 & 11,0 & 11,0 & 11,0 & 11 & \\
\hline $\mathrm{BC}$ & 4,0 & 29,0 & 34,0 & 35,0 & 35,0 & 36,0 & 37,0 & 38,0 & 38,0 & 38,0 & 39,0 & 39,0 & 39 & \\
\hline $\mathrm{KC}$ & 4,0 & 20,0 & 24,0 & 24,5 & 25,0 & 25,0 & 25,5 & 25,5 & 26,0 & 26,0 & 26,5 & 26,5 & 26,5 & 562,5 \\
\hline B & 5,0 & 6,0 & 6,5 & 6,5 & 6,5 & 6,5 & 6,5 & 7,0 & 7,0 & 7,0 & 7,0 & 7,0 & 7,0 & 40 \\
\hline $\mathrm{K}$ & 3,0 & 9,0 & 10,0 & 10,0 & 10,0 & 10,0 & 10,0 & 10,0 & 10,0 & 10,0 & 10,0 & 10,0 & 10,0 & 233,3 \\
\hline$S$ & 3,0 & 19,0 & 20,0 & 20,0 & 20,0 & 20,0 & 20,0 & 20,0 & 20,0 & 20,0 & 20,0 & 20,0 & 20,0 & 566,7 \\
\hline C & 19,0 & 34,0 & 34,0 & 34,0 & 34,0 & 34,0 & 34,0 & 34,0 & 34,0 & 34,5 & 34,5 & 34,5 & 34,5 & 81,6 \\
\hline
\end{tabular}

Keterangan: B = Gelatin Ikan Bandeng, $\mathrm{K}=$ Gelatin Komersil, $\mathrm{S}=$ Gelatin Sapi, C = Kitosan

IP dihitung sebagai rasio volume pengembangan jam ke-12 terhadap ke-0

unit volume terkecil pengamatan adalah $0,5 \mathrm{ml}$

pada sifat fisik dari kompleks gelatin-kitosan.

Walaupun terdapat tiga jenis ikatan/interaksi, ikat silang kovalen merupakan yang terkuat dan paling berpengaruh terhadap sifat fisik gelatin.

Indeks

pengembangan mengindikasikan terbentuknya ikat silang (Uranga, et al., 2019).

Seluruh sampel ketika kering membentuk lapisan film yang tidak larut dalam air, menjadi indikasi terbentuknya ikat silang. Serbuk hasil ikat silang gelatin-kitosan berwarna coklat hingga coklat kehitaman, baik yang menggunakan glutaraldehid maupun sukrosa teroksidasi, yang berbeda dengan gelatin yang tidak diikat silang (lihat tabel 2). Nilai indeks pengembangan terbesar adalah pada kelompok ikat silang GBC 1 dan nilai terendah pada SBC 2. Nilai indeks pengembangan yang kecil menunjukkan ikatan silang yang terbentuk tinggi dan menghalangi terjadinya hidrasi oleh air. Gugus-gugus seperti amin dan hidroksil pada kitosan dan amin pada gelatin telah diikat oleh glutaraldehid dan sukrosa teroksidasi. Hal ini dibuktikan juga pada nilai indeks pengembangan blangko $\mathrm{BC}$ dan $\mathrm{KC}$ serta bahan baku gelatin komersil dan standar gelatin sapi yang sangat tinggi, yang menunjukkan ikat silang tidak terjadi pada kompleks ini sehingga mudah terhidrasi oleh air. Selain itu, struktur ikat silang yang kompak juga berefek pada 'pembengkakan' yang terjadi terbatas. Berbeda dengan yang tidak diikat silang dengan gelatin, struktur dapat 'membengkak' lebih bebas karena tidak dibatasi oleh ikat silang. Perbedaan hasil pada gelatin bandeng kemungkinan disebabkan oleh kualitasnya yang lebih rendah daripada gelatin sapi sehingga lebih sukar untuk larut. 


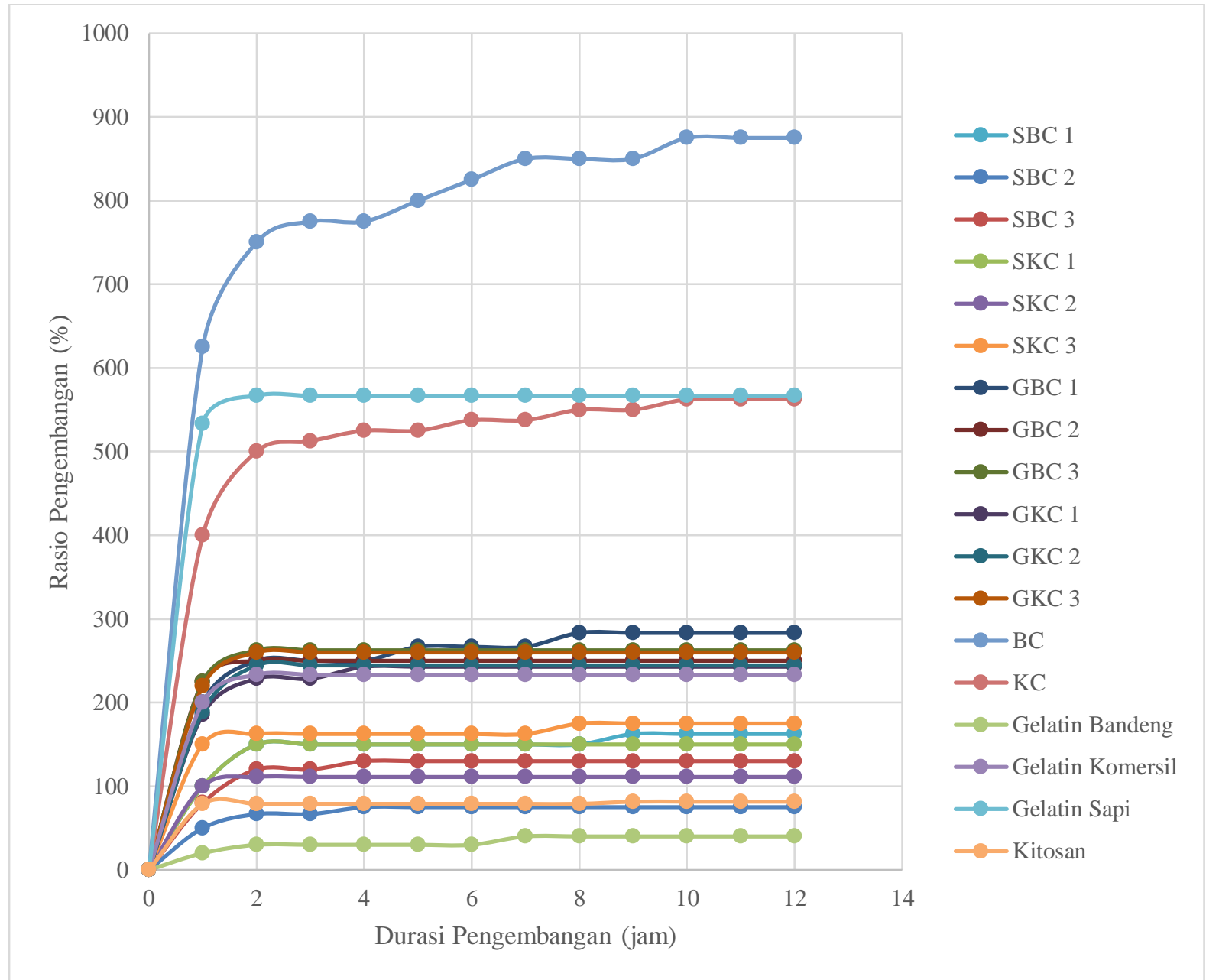

Gambar 1. Kurva indeks pengembangan terhadap waktu

Kompleks gelatin-kitosan ikat silang glutaraldehid (GBC dan GKC) memiliki nilai indeks pengembangan berkisar antara 242$283 \%$, atau mengembang sekitar dua kali lipat. Efektifitas pengikatan glutaraldehid terhadap gelatin sisik ikan Bandeng dan gelatin komersil relatif sama besar. Menurut Bigi dkk (2001), semakin tinggi konsentrasi glutaraldehid yang digunakan sebagai bahan pengikat silang maka volume pengembangannya akan semakin rendah (Bigi, Cojazzi, Panzavolta, Rubini, \& Roveri, 2001). Hasil penelitian Bigi berbeda dengan hasil penelitian ini. Kenaikan konsentrasi pengikat silang glutaraldehid tidak berpengaruh signifikan terhadap penurunan volume pengembangan, baik itu yang mengunakan gelatin ikan Bandeng (GBC 1, GBC 2 dan GBC 3) maupun gelatin komersil (GKC 1, GKC 2 dan GKC 3). Kemungkinan konsentrasi glutaraldehid yang digunakan sudah cukup tinggi sehingga peningkatan konsentrasi tidak berpengaruh terhadap indeks pengembangan. Gugus amin atau hidroksil pada gelatin dan kitosan telah bereaksi seluruhnya sehingga molekul pengikat silang berikutnya tidak lagi dapat mengikat gelatin dan kitosan.

Indeks pengembangan untuk kompleks gelatin-kitosan yang diikat sukrosa 
teroksidasi memiliki nilai berkisar $75-175 \%$. Nilai volume pengembangan untuk kelompok SBC 2 dan SKC 2 (dibuat dari sukrosa dan natrium periodat dengan perbandingan $1: 3$ mol) lebih rendah dibandingkan dengan kelompok lainnya. Kemungkinan hasil tersebut dipengaruhi oleh rasio bahan pengikat silang yang digunakan. Menurut Jalaja dan James (2015), untuk menyempurnakan oksidasi dari sukrosa teroksidasi dibutuhkan tiga ekivalen natrium periodat sehingga menghasilkan empat karbonil (tetraaldehid) (Jalaja \& James, 2015). Dibandingkan dengan dialdehid yang hanya memiliki dua gugus karbonil, tetraaldehid pada sukrosa teroksidasi dapat berikatan silang dengan gelatin dan kitosan lebih tinggi. Hal inilah yang menyebabkan penurunan volume pengembangan pada kelompok SBC 2 dan SKC 2 karena digunakan rasio sukrosa dan natrium periodat sebesar 1:3.

Gelatin yang diikat silang mampu bertahan dalam air mendidih, titik leleh gel meningkat, kemampuan mengembang menurun, dan resistensi terhadap tekanan mekanik meningkat (Schrieber \& Gareis, 2007). Kemampuan mengembang menurun dikarenakan gelatin yang diikat silang, kerapatan jaringan polimernya meningkat dan berkurangnya ruang kosong yang tersedia sehingga membuat sulitnya proses difusi dari molekul pelarut (Cui, Jia, Guo, Liu, \& Zhu, 2014). Peningkatan volume pengembangan yang sangat signifikan pada jam pertama dan penurunan laju volume pengembangan pada jam berikutnya merupakan hal yang umum (Uranga, et al., 2019). Kelompok SBC 2 menunjukkan hasil indeks pengembangan yang paling baik karena memiliki peningkatan volume yang paling rendah yaitu sebesar $75 \%$.

\section{KESIMPULAN}

Berdasarkan penelitian yang telah dilakukan dapat simpulkan bahwa kompleks gelatin-kitosan dapat diikat silang dengan glutaraldehid dan sukrosa teroksidasi. Kompleks gelatin kitosan yang diikat silang menggunakan sukrosa teroksidasi dengan perbandingan sukrosa dan natrium periodat 1 : 3 (SBC 2), menunjukkan nilai indeks pengembangan yang paling baik.

\section{DAFTAR PUSTAKA}

Aider, M. (2010). Chitosan application for active bio-based films productionand potential in the food industry: review. $L W T$ Food Science Technology, 43, 837-842.

Benbettaïeb, N., Karbowiak, T., Brachais, C.H., \& Debeaufort, F. (2015). Coupling tyrosol, quercetin or ferulic acid and electron beam irradiation to cross-link chitosan-gelatin films: A structurefunction approach. European Polymer Journal, 67, 113-127.

Bigi, A., Bracci, B., Cojazzi, G., Panzavolta, S., \& Roveri, N. (1998). Drawn gelatin films with improved mechanical properties. Biomaterials, 19, 2335-2340.

Bigi, A., Cojazzi, G., Panzavolta, S., Rubini, K., \& Roveri, N. (2001). Mechanical and thermal properties of gelatin films at different degrees of glutaraldehyde crosslinking. Biomaterials Volume 22 Issue 8, 763-768.

Cui, L., Jia, J., Guo, Y., Liu, Y., \& Zhu, P. (2014). Preparation and characterization of IPN hydrogels composed of chitosan and 
gelatin cross-linked by genipin. Carbohydrate Polymers Volume 99, 31-38. Direktorat Produksi dan Usaha Budidaya. (2016). Peta Sentra Produksi Perikanan Budidaya. Kementerian Kelautan dan Perikanan Republik Indonesia.

Dragusin, D. M., Vlierberghe, S. V., Dubruel, P., Dierick, M., Hoorebeke, L. V., Declercq, H. A., . . Stancu, I. C. (2012). Novel gelatin-PHEMA porous scaffolds for tissue engineering applications. Soft Matter, 8(37), 9589-9602.

El-Feky, G. S., Zayed, G. M., Elshaier, Y. A., \& Alsharif, F. M. (2018). Chitosan-Gelatin Hydrogel Crosslinked With Oxidized Sucrose for the Ocular Delivery of Timolol Maleate. Journal of Pharmaceutical Sciences Volume 107 Issue 12, 3098-3104.

Erizal, Perkasa, D. P., Abbas, B., \& S., S. G. (2013). Sintesis Kopolimer Ikatan Silang Gelatin Sisik Ikan-Kitosan Menggunakan Iradiasi Gamma. Jurnal Ilmiah Aplikasi Isotop dan Radiasi Vol. 9 No. 2, 101-112.

Farris, S., Song, J., \& Huang, Q. (2010). Alternative reaction mechanism for thecross-linking of gelatin with glutaraldehyde. J Agric Food Chem, 58, 998-1003.

Hamzah, N., Nurmi, Mukhriani, \& Ismail, A. (2019). Karakter Indeks Pengembangan Gelatin Taut Silang dengan Sukrosa Teroksidasi dan Glutaraldehid. ad-Dawaa' - Journal of Pharmaceutical Sciences (DJPS), 2(1), 22-28.

Hoque, M., Benjakul, S., \& Prodpran, T. (2011). Properties of film from cuttlefish(Sepia pharaonis) skin gelatin incorporated with cinnamon, clove andstar anise extracts. Food Hydrocolloids, 25, 1085-1097.

Hosseini, S. F., Rezaei, M., Zandi, M., \& Ghavi, F. F. (2013). Preparation and functional properties of fish gelatinchitosan blend edible films. Food Chemistry Volume 136 Issue 3-4, 14901495.

Huang, T., Tu, Z.-c., Shangguan, X., Sha, X., Wang, H., Zhang, L., \& Bansal, N. (2019). Fish gelatin modifications: A comprehensive review. Trends in Food Science \& Technology Volume 86, 260269.
Huang, X., Zhang, Y. Q., Zhang, X. M., Xu, L., Chen, X., \& Wei, S. C. (2013). Influence of radiation crosslinked carboxymethyl-chitosan/gelatin hydrogel on cutaneous wound healing. Mater. Sci. Eng. C., 33(8), 4816-4824.

Jalaja, K., \& James, N. R. (2015). Electrospun gelatin nanofibers: A facile cross-linking approach using oxidized sucrose. International Journal of Biological Macromolecules Volume 73, 270-278.

Jătariu (Cadinoiu), A. N., Danu, M., Peptu, C. A., Ioanid, G., Ibanescu, C., \& Popa, M. (2013). Ionically and covalently crosslinked hydrogels based on gelatin and chitosan. Soft Mater, 11(1), 7616-7627.

Jătariu (Cadinoiu), A. N., Popa, M., Curteanu, S., \& Peptu, C. A. (2011). Covalent and ionic co-cross-linking - an original way to prepare chitosan-gelatin hydrogels for biomedical applications. J. Biomed. Mater. Res. A., 98(3), 342-350.

Jayasuriya, A. C., \& Kibbe, S. (2010). Rapid biomineralization of chitosan microparticles to apply in bone regeneration. J. Mater. Sci.: Mater. Med., 21(2), 393-398.

Koser, S. A., Chinn, B. D., \& Saunders, F. (1938). Gelatin as a Source of GrowthPromoting Substances for Bacteria. $J$. Bacteriol, 36(1), 57-65.

Li, X., Ma, X. X., D., F. D., \& Zhu, C. H. (2012). New suitable for tissue reconstruction injectable chitosan/collagen-based hydrogels. Soft Matter, 8(14), 3781-3790.

Mishra, D., Bhunia, B., Banerjee, I., Datta, P., Dhara, S., \& K., M. T. (2011). Enzymatically crosslinked carboxymethylchitosan/gelatin/nano-hydroxyapatite injectable gels for in situ bone tissue engineering application. Mater. Sci. Eng. C., 31(7), 1295-1304.

Patel, S., Srivastava, S., Singh, M. R., \& Singh, D. (2018). Preparation and optimization of chitosan-gelatin films for sustained delivery of lupeol for wound healing. International Journal of Biological Macromolecules Volume 107 Part B, 1888-1897. 
Qian, Y., Zhang, K., Chen, F., Ke, Q., \& Mo, $X$. (2011). Cross-linking of gelatin and chitosan complex nanofibers for tissueengineering scaffolds. $J$ Biomater $S c i$ Polym Ed, 22(8), 1099-1113.

Qiao, C., Ma, X., Zhang, J., \& Yao, J. (2017). Molecular interactions in gelatin/chitosan composite films. Food Chemistry Volume 235, 45-50.

Rivero, S., García, M., \& Pinnoti, A. (2010). Correlations between structural, barrier, thermal and mechanical properties of plasticized gelatin films. Innovative Food Sci Emerging Technol, 11(2), 369-375.

Schrieber, R., \& Gareis, H. (2007). Gelatine Handbook: Theory and Industrial Practice. Germany: Wiley-VCH.

Stancu, I. C., Lungu, A., Dragusin, D. M., Vasile, E., Damian, C., \& Iovu, H. (2013). Porous Gelatin-Alginate-Polyacrylamide Scaffolds with Interpenetrating Network Structure: Synthesis and Characterization. Soft Mater., 11(4), 384-393.

Staroszczyk, H., Sztuka, K., Wolska, J., Wojtasz-Pająk, A., \& Kołodziejska, I. (2014). Interactions of fish gelatin and chitosan in uncrosslinked and crosslinked with EDC films: FT-IR study. Spectrochimica Acta Part A: Molecular and Biomolecular Spectroscopy Volume 117, 707-712.
Tylingo, R., Gorczyca, G., Mania, S., Szweda, P., \& Milewski, S. (2016). Preparation and characterization of porous scaffolds from chitosan-collagen-gelatin composite. Reactive and Functional Polymers Volume 103, 131-140.

Uranga, J., Puertas, A. I., Etxabide, A., Dueñas, M. T., Guerrero, P., \& Caba, K. d. (2019). Citric acid-incorporated fish gelatin/chitosan composite films. Food Hydrocolloids Volume 86, 95-103.

Wang, Y. F., Hong, Q. F., Chen, Y. J., Lian, X. X., \& Xiong, Y. F. (2012). Surface properties of polyurethanes modified by bioactive polysaccharide-based polyelectrolyte multilayers. Colloids Surf. B., 100, 77-83.

Wang, Y., Wang, Y., Guo, X., Xiong, Y., Guoa, M., \& Wang, X. (2015). Microbial Transglutaminase and Tyrosinase Modified Gelatin-Chitosan Material. Soft Materials, 13(1), 32-38.

Wu, H. D., Ji, D. Y., Chang, W. J., Yang, J. C., \& Lee, S. Y. (2012). Chitosan-based polyelectrolyte complex scaffolds with antibacterial properties for treating dental bone defects. Mater. Sci. Eng. C., 32(2), 207-214. 